Їгнатов О. М., К.ю.н., с.н.с., завідувач кафедри трудового права, права соціального забезпечення та кримінального права Інститут економіки та права (філія) ОУП ВПО «Академія праці та соціальних відносин» в м. Севастополі

\title{
ЗАГАЛЬНИЙ КРИМІНОЛОГІЧНИЙ АНАЛІЗ ЗАКОНУ УКРАЇНИ «ПРО ЗАСАДИ ЗАПОБІГАННЯ ТА ПРОТИДІЇ КОРУПЦЇ̈» ЯК ЗАХОДУ ПРОТИДІї КОРУПЦІї
}

Анотація. Стаття присвячена дослідженню проблем протидії корупції. 3 урахуванням сучасної політичної та соціально-економічної ситуації здійснено спробу провести критичний з точки зору ефективності аналіз прийняття Закону України «Про засади запобігання і протидії корупції як антикорупційного заходу.

Ключові слова: корупція, закон, протидія.

Постановка проблеми. 31991 року Україна вступила на шлях побудови незалежної демократичної держави. Неминучою стала задача реформування державного, суспільного та економічного устрою. Незважаючи на те, що втілення у життя необхідних перетворень відбувалося складно і суперечливо, що не могло не вплинути кардинально на зміну способу життя більшості людей і суспільства в цілому; не зважаючи на те, що процеси демократизації політичного та економічного життя країни все ще супроводжуються загостренням суспільних відносин, породжують нові соціальні явища, які не тільки негативно впливають на життя людей, але й стають базою для вчинення злочинів [7, 3], Україна досягла певних результатів у справі будівництва цивілізованої, демократичної, соціальної держави. Доказом цього $€$ світове визнання України та активний процес iii інтеграції до основних інституцій $Є \mathrm{C}$ та світу.

Однак, нажаль, існують і загрози, які супроводжують нашу країну впродовж всього їі шляху, однією з яких є корупція, за якою Україна займає далеко не останнє місце у світі. Загалом стан корупції в Україні характеризується як такий, що загрожує національній безпеці країни та ускладнює вирішення проблеми національної та звиокремлення нерозв'язаних проблем єдності Української держави $[1,6]$.

Аналіз останніх досліджень та виокремлення нерозв'язаних задач. Проблемі протидії корупції в усі часи приділялася значна увага. Значний внесок в справу дослідження та розробки заходів протидії корупції зробили такі вчені, як: П. П. Андрушко, Л. Іे. Аркуша, Л. В. Багрій-Шахматов, М. ІІ. Бажанов, Ю. В. Баулін,
В. İ. Борисов, В. М. Гаращук, А. А. Герцензон, В. О. Глушков, В. В. Голіна, Іे. П. Голосніченко, İ. М. Даньшин, О. О. Дудоров, В. Д. Дурманов, А. А. Жижиленко, А. П. Закалюк, В. С. Зеленецький, О. Г. Кальман, В. Ф. Кириченко, В. А. Клименко, В. К. Колпаков, М. Й. Коржанський, В. С. Кузьмичов, П. С. Матишевський, М. Іे. Мельник, Д. Г. Михайленко, В. Г. Лукашевич, В. С. Лукомський, Г. А. Матусовський, B. О. Навроцький, Є. В. Невмержицький, М. В. Салтевський, О. Я. Свєтлов, Ї. В. Сервецький, В. В. Сташис, О.В.Терещук, І. К. Туркевич, М. І.. Хавронюк, А. Н. Трайнин, Б. С. Утевський, В. І̇. Шакун, С. А. Шалгунова, В. Ю. Шепітько та ін.

Однак, незважаючи на значну увагу до даної проблематики, багато аспектів протидії корупції викликають чимало запитань. Це обумовлено, перш за все, динамічністю розвитку нашого суспільства, появою нових проявів корупції та, відповідно, нових проблем протидії. Однак, поряд 3 цим, виникають питання й щодо прийняття тих чи інших фундаментальних, з точки зору протидії даному явищу, рішень. В повній мірі це стосується й прийняття Закону України «Про засади запобігання і протидії корупції».

Метою даної статті $€$ критичний, з точки зору ефективності, аналіз прийняття Закону України «Про засади запобігання і протидії корупції як антикорупційного заходу.

Викладення основного матеріалу. Усі цивілізовані країни світу відносять сьогодні корупцію до найнебезпечніших негативних криміногенних явищ соціально-політичного характеру. В Україні через масштаби поширеності у всіх сферах життєдіяльності та повну відсутність у чиновників страху відповідальності, нерідко корупцію недарма, на жаль, відносять до окремого виду насильства коли населення кожного дня стикається якщо не з прямим вимаганням хабара, так зі штучно створеними «представниками держави» умовами, коли без хабара неможливо вирішити практично жодної справи чи питання.

На подолання цього негативного явища у нашому суспільстві Верховна Рада України прийняла 
Закон України «Про засади запобігання і протидії корупції від 7 квітня 2011 року № 3206-VI, який набрав чинності 1 липня 2011 року (крім положення щодо декларування витрат (статей 11 і 12), яке набирає чинності з 1 січня 2012 року) [6].

3 моменту набрання чинності вказаним Законом минуло вже півроку. Однак поки що ніяких, навіть самих незначних, відблисків будь-яких помітних змін у суспільстві не відбулося. Безперечно минуло зовсім мало часу. Але, як показує життя, коли держава в обличчі можновладців обирає певний дійсно потрібний ій курс у тій, чи інший сфері, то суттєві зміни ми відчуваємо майже наступного дня - гучні факти«виявлення», резонансні розслідування, переслідування тощо.

Чому ж нічого подібного не відбувається після прийняття такого довгоочікуваного, такого значущого і знакового закону? Гучних кримінальних справ не має, статистика правоохоронних органів та суду за останні півроку майже не відрізняється від попередніх тощо. Можливо «вороги держави» затаїлися та вичікують? А можливо прийнятий новий антикорупційний закон $€$ черговою вакуумною бомбою, яка замість повітря повинна поглинати соціальну напруженість, що має місце у суспільстві через вкрай високий рівень корумпованості нашого життя? Або новий закон нічого нового та ефективного в собі не несе та нічим, крім нових юридичних формулювань та більш складних речових обертів, за своєю суттю, не відрізняється від попереднього?

Безумовно недоліки у нового антикорупційного закону є. І̇ чим глибше в опозиції до авторів даної законодавчої ініціативи знаходиться той, хто його аналізує, тим більше їх він нараховує. Однак, поряд з цим, цей закон має низку позитивних, прогресивних відмінностей.

Так, термінологія нового закону та визначення основних інститутів узгоджені із Конвенцією $\mathrm{OOH}$ проти корупції та Кримінальною і Цивільною конвенціями Ради Європи проти корупції (зокрема, поняття корупції, конфлікту інтересів, корупційного правопорушення тощо). Закон чіткіше визначає зміст таких понять, як «близькі особи» та «члени сім'ї». Даний закон дещо чіткіше, на відміну від попереднього, визначає коло суб'єктів відповідальності за корупційні правопорушення.

Обмеження (використання службового становища, одержання дарунків, робота близьких осіб, фінансовий контроль) також встановлені для посадових осіб юридичних осіб публічного права, які одержують заробітну плату за рахунок державного чи місцевого бюджетів. Крім того, обмеження, встановлені антикорупційним законодавством, поширюються й на членів окружних/ територіальних та дільничних виборчих комісій, а також на помічників-консультантів народного депутата України на громадських засадах.
Окреме положення закону визначає конфлікт інтересів на публічній службі, заходи щодо попередження його виникнення та порядок його врегулювання. Запроваджено спеціальну перевірку при прийнятті на роботу. Законом прямо встановлено обмеження мати у безпосередньому підпорядкуванні або бути безпосередньо підпорядкованими у зв'язку з виконанням повноважень близьким особам.

Органам державної влади, органам місцевого самоврядування забороняється одержувати від фізичних, юридичних осіб безоплатні майно та послуги. Чіткіше визначено правовий режим дарунка (пожертви) та передбачено вичерпний перелік випадків заборони отримання дарунка. Дарунки ж, одержані особами, уповноваженими на виконання функцій держави, як подарунки державі, Автономній Республіці Крим, територіальній громаді, державним або комунальним установам чи організаціям, $є$ відповідно державною або комунальною власністю і передаються органу, установі чи організації у порядку, визначеному Кабінетом Міністрів України.

Закон також встановлює зразок бланка декларації про майно, доходи, витрати і зобов'язання фінансового характеру, у якому передбачено подання відомостей про закордонне майно, доходи, витрати і зобов'язання фінансового характеру.

Новий закон більш чітко визначає й коло суб'єєтів, які можуть здійснювати заходи щодо запобігання та протидії корупції, а також питання координації реалізації органами виконавчої влади антикорупційної стратегії. Законом передбачається ведення Єдиного державного реєстру осіб, які вчинили корупційні правопорушення, - єдиної бази даних, в якій зосереджуватимуться відомості про всіх осіб, яких притягнуто до відповідальності за вчинення корупційних правопорушень тощо. Законом також закріплено здійснення Міністерством юстиції антикорупційної експертизи проектів нормативно-правових актів тощо.

Қажучи, в цілому, про позитивні чи негативні сторони даного закону, хотілось би щоб він, як й будь-який інший законодавчий акт, що приймається у нашій країні відповідав постулату, що визначив майже двісті п’ятдесят років назад великий кримінолог Чезаре Бекаріа: «Хотите предупредить преступления? Сделайте так, чтоб законы были ясными, простыми, чтобы вся сила нации была сосредоточена на их защите и чтобы ни одна часть этой силы не направлялась на их уничтожение. Сделайте так, чтобы законы меньше покровительствовали сословиям, чем самим людям. Сделайте так, чтобы люди боялись их и только их. ... Если человек с чувствительной душой бросит взгляд на Уложение хорошо составленных законов и найдет, что он потерял только печальную свободу 
причинять другим зло, то он будет принужден благословить престол и того, кто его занимает» [5, 151, 152].

Отже, дискусії навколо вад та переваг даного (як і будь-якого іншого) закону насправді можуть бути нескінченими. Та чи лише у досконалості закону насправді істина причина того, працює він чи не працює?

Будь-який самий досконалий за своїм змістом закон сам по собі не запрацює. Для цього потрібна, перш за все, політична воля керівництва держави (щоб народ «благословил престол и того, кто его занимает» треба спочатку потурбуватися про цей народ). Суттєво вплинути на корупцію, обмежити іiі рівень, можливо лише одночасно та по всім напрямкам вирішуючи ті проблеми нашого соціуму, які їі породжують. А реалізація таких масштабних заходів без наявності вказаної волі не можлива.

Антикорупційна політика, як складова частина державної політики, повинна будуватися та реалізовуватися, перш за все, на вищому щаблі політичного керівництва країни з опорою та максимально можливому співробітництві з інститутами громадянського суспільства. Навіть обмежити рівень корупції, не кажучи вже про гучні плани iï викорінити, лише каральними та обмежуючими заходами не можливо. Приказати корупції більше не існувати, а чиновникам на зловживати своїм становищем - не можна. Потрібен комплекс заходів протидії.

По-перше, необхідно належним чином корегувати економічні реформи, виводячи на перше місце їх соціальну спрямованість та роблячи акцент на необхідності зменшення монополії держави на надання «державних» послуг, як за рахунок створення «здорової» конкуренції, так й за рахунок надання можливості вирішення частини соціальних задач інститутам громадянського суспільства при залишенні за державою контрольних функцій.

По-друге, потрібна перебудова на нових принципах всієї структури державної служби. Корупційні діяння часто вчиняються в складних специфічних і конфіденційних видах державної діяльності, де розібратися непрофесіоналу складно $[4,82]$. Державна служба повинна бути побудована виходячи з орієнтації на принцип «реєструвати та повідомляти, а не дозволяти». Максимальне обмеження дискреції представників державної влади повинне забезпечити максимальне скорочення (принаймні, на низовому рівні) обсягу управлінських рішень, коли останні залежать від розсуду державного службовця, обмеження його компетенції формалізованими і чітко регульованими «реєстраційними функціями» - тобто «максимальне зменшення монопольної влади окремого бюрократа» [3, 322]. Поряд з цим необхідно позбавлятися від позабюджетних фондів - як джерел фінансування та оплати праці службовцям.

По-третє, необхідне подальше забезпечення реформування податкової системи та вдосконалення податкового законодавства з метою детінізації економіки, у тому числі в частині унеможливлення сприяння свавіллю податківців на місцях.

По-четверте, необхідне реформування на основі прозорості, незалежності та гідного забезпечення всієї судової системи. Потрібно розвивати адміністративну юстицію в країні.

По-п'яте, запорукою ефективної протидії корупції у країні $€$ відповідні зміни в ідеологічній сфері. Треба пам'ятати, що у корупції завжди два контрагенти (якщо при вчиненні корупційного правопорушення двома сторонами «за згодою» не враховувати наявність третьої - потерпілої сторони - держави, суспільства в цілому, його окремих представників). Як зазначають фахівці, протидія корупції в Україні ускладнюється тим, що українське суспільство сприймає корупцію як невід'ємну частину процесу свого розвитку $[1,7]$. Отже без розвитку антикорупційної культури населення, підвищення його громадянської та правової свідомості ефективна протидія їй неможлива. Далеко не останню роль у цьому відіграють 3Mі, які повинні не залакувати населення тотальною корумпованістю всіх щаблів суспільства, лише підвищуючи до критичного рівня соціальну напруженість, а інформувати про потенційні загрози (аж до конкретних окремих службовців) та засоби захисту себе від проявів корупції.

Окремо також слід відзначити проблему протидії організованій злочинності у контексті ії зв'язку з корупцією. Необхідно щоб кожен аспект протидії корупції, по можливості, був взаємопов'язаний iз заходами протидії організованій злочинністю i відмиванню незаконних доходів.

Таким чином, як можна бачити, протидія корупції не може бути забезпечена прийняттям одного закону. При цьому, для успішної реалізації комплексу антикорупційних заходів необхідне не лише узгодження цього закону з іншими нормативно-правовими актами, але й системне прийняття низки радикальних нормативно-правових актів антикорупційної спрямованості та внесення змін в діючі.

Однак, тут виникає чимало труднощів. İ пов'язані вони, як не диво, з самою корупцією. Як відомо, в детермінаційному ланцюгу злочинності саме політичні інтереси і конфлікти (відношення) нерідко визначають й економічні, й соціальні відношення: їх негативні сторони, що впливають на злочинність, у ряді випадків є первинними $[2,66]$. Політична конкуренція (яка часто не 
визнає обмежень щодо засобів досягнення цілі) обумовлює лобіювання політичних інтересів, що не рідко здійснюється через корумпований вплив на діяльність законодавчих органів та законодавчий процес в країні в цілому. Тому завжди «причиною» протистояння протидії корупції буде «не вподобання» шляхів та методів протидії, які пропонують політичні конкуренти. Слід зазначити, що для тих, хто боїться активного наступу на корупцію, така позиція є цілком вигідною, незалежно на чому ти боці знаходишся.

Отже без зменшення впливу корупції на законотворчу діяльність (перш за все, через спрощення процедури притягнення депутатів до відповідальності, в тому числі кримінальної та посилення контролю за законотворчістю), а в кінцевому підсумку й на процес виборів у країні, ефективна протидія їй не можлива.

Щодо розрахунку на зниження чи взагалі зняття соціальної напруженості. Дійсно буває, що прийняття того чи іншого закону відбувається під тиском з боку світової спільноти, залишаючись лише оболонкою формально виконаних вимог, або закон приймається бо треба дати народу хоч щось, треба хоч щось зробити на даний момент. Однак ніякого а ні ефекту, а ні позитиву такий крок принести не може, тим більше відносно проблеми протидії корупції.

Актуалізувати у свідомості населення проблему корупції, «підготувавши» його до появи такого потрібного і важливого закону, вдалося й через «відміну» попереднього закону. Так, 11 червня 2009 року Верховна Рада ухвалила так званий пакет законів щодо запобігання і протидії корупції, основним серед яких був закон «Про засади запобігання і протидії корупції». Ці закони мали вступити в дію 31 січня 2010 року. У прикінцевих положеннях закону «Про засади запобігання і протидії корупції» 2009 року записано: «Визнати такими, що втрачають чинність з 1 січня 2011 року закон України «Про боротьбу з корупцією», Постанову Верховної Ради України від 5 жовтня 1995 року «Про порядок введення в дію закону України «Про боротьбу з корупцією». Але ці акти так і не вступили в дію, оскільки рішення про введення їх в дію було скасоване законом від 21 грудня 2010 року. А ось безладу як у думках, так й діях, як пересічних громадян, так й правозастосувавчів з приводу відмітки на офіційному сайті Верховної Ради щодо втрати чинності законом України «Про боротьбу з корупцією» було чимало.

Зняти чи знизити соціальну напруженість в нашому суспільстві лише прийняттям, а не фактичним виконанням законів сьогодні не можливо. В обіцянки ніхто вже ні вірить. Соціальна напруженість, як відомо, може бути викликана не тільки прагненням досягти якої-небудь мети, але i різного роду помилками або некомпетентністю лідерів тощо. Найбільш гостро соціальна напруженість проявляється не у взаємодії великих соціальних груп, а взаємодії між державною владою на всіх рівнях і населенням взагалі. Різного роду помилки та порушення, спочатку мінімальні, поступово накопичуючись, можуть досягнути критичного рівня, коли їх усвідомлення призведе до соціального вибуху.

Прийняття ж антикорупційного закону, який заздалегідь не здатен «працювати», або ж прийняття відповідного закону без вжиття комплексу необхідних заходів та узгодження його з іншим законодавством країни, а рівно як блокування його дії зацікавленими політичними силами, лише призводить до зростання впевненості населення в ігноруванні порушення їх прав з боку корупціонерів, відповідно, у нівелюванні його інтересів 3 боку влади, неспроможності впливу на владу та протистоянні іiі свавіллю. Усе це лише загострює соціальну напруженість, підвищує іiі до критичного рівня, одночасно орієнтуючи населення на активне протистояння владі в цілому.

Висновки. Отже, прийняття Закону України «Про засади запобігання і протидії корупції» $€$ важливим та необхідним кроком вперед у протидії корупції в нашій країні. Однак, як можна бачити, протидія корупції не може бути забезпечена прийняттям одного Закону. Тому, подальша «робота» даного закону, а також вживання комплексу інших, в тому числі по зазначених вище напрямках, антикорупційних заходів наочно продемонструють нам наявність чи відсутність політичної волі керівництва країни, а також зацікавленість як окремих політичних сил, так й населення в цілому у протидії корупції в нашому суспільстві.

\section{Jimepamypa:}

1. Дрьомов С. В. Корупція в Україні: причини поширення та механізми протидії. Зелена книга державної політики : монографія / С. В. Дрьомов, Ю. Г. Кальниш, Г. О. Усатий [та ін.]. - К. : Видавничий центр НУБіП України, 2011. - 91 с.

2. Кудрявцев В. Н. Причины преступности в России: Криминологический анализ / В. Н. Кудрявцев, В. Е. Эминов. - М. : Норма, 2006. - 112 с.

3. Литвак О. М. Державний контроль за злочинністю (кримінологічний аспект) : дис.... д-ра. юрид. наук : 12.00 .08 / О. М. Литвак. - Х., 2001. - 370 с.

4. Лунєєв В. В. Коррупция, учтенная и фактическая / В. В. Лунєєв // Государство и право, 1996. - № 8. - C. 78-90.

5. О преступлениях и наказаниях / Ч. Беккария / Сост. и предисл. В. С. Овчинского. - М. : ИНФРА-М, 2011. - VI. - 184 c.

6. Про засади запобігання і протидії корупції : Закон України від 07.04.2011 року № 3206-VI // Відомості Верховної Ради України (ВВР), 2011. - № 40. - Ст. 404.

7. Шакун В. І̇. Суспільство і злочинність / В. І̇. Шакун. - К. : Атіка, 2003. - 784 с. 
Игнатов А. Н. Общий криминологический анализ Закона Украины «Об основах предотвращения и противодействия коррупции» как мера противодействия коррупции

Аннотация. Статья посвящена исследованию проблем противодействия коррупции. С учетом сложившейся политической и социальноэкономической ситуации сделана попытка критически с точки зрения эффективности проанализировать принятие Закона Украины «Про основы предотвращения и противодействия коррупции» как антикоррупционную меру.

Ключевые слова: коррупция, закон, противодействие.
Ignatov A. N. Global criminology analysis of Ukraine Law «About principles of prevention and counteraction to the corruption» as the west of counteraction to the corruption

Summary. The article is devoted research of problems of counteraction a corruption. Taking into account the folded political and socio-economic situation an attempt is done critically from point of efficiency to analyse passing an Act of Ukraine «About bases of prevention and counteraction a corruption» as anticorruption measure.

Key words: corruption, law, counteraction. 